\title{
The IGF/IGFBP system in CNS malignancy
}

\author{
W Zumkeller, M Westphal
}

\begin{abstract}
The insulin-like growth factor (IGF) system includes IGF-I and IGF-II, the type I and type II IGF receptors, and specific IGF binding proteins (IGFBP-1 to IGFBP-6). These factors regulate both normal and malignant brain growth. Enhanced expression of IGF-I and IGF-II mRNA transcripts has been demonstrated in gliomas, meniningiomas, and other tumours. Abnormal imprinting of IGF-II occurs in gliomas, medulloblastomas, and meningiomas. Both types of IGF receptor are expressed in gliomas and, in particular, the type I IGF receptor appears to be upregulated in malignant brain tissue. Antisense IGF-I receptor mRNA induces an antitumour response, resulting in complete brain tumour regression. Clinical trials for the treatment of brain tumours in humans based on a gene transfer protocol using IGF-I receptor antisense are under way. All six IGFBPs are expressed to a variable extent in brain tumours. High concentrations of IGFBP-2 are found in cerebrospinal fluid from patients with malignant central nervous system tumours; therefore, IGFBP-2 might be a useful marker for these tumours. IGFBP-4 appears to be a negative regulator of tumour proliferation. Both in vitro and in vivo experiments suggest that the IGF system represents an important target for the treatment of malignant central nervous system tumours and the ongoing trials should provide valuable information for future therapeutic approaches. (f Clin Pathol: Mol Pathol 2001;54:227-229)
\end{abstract}

Keywords: insulin-like growth factor; insulin-like growth factor binding protein; central nervous system; brain tumours

Martin-Luther-

University

Halle-Wittenberg,

University Hospital,

Department of

Pediatrics,

Ernst-Grube-Str. 40, 06097 Halle/Saale,

Germany

W Zumkeller

University Hospital

Eppendorf,

Department of

Neurosurgery,

Martinistr. 52, 20246

Hamburg, Germany

$M$ Westphal

Correspondence to:

Dr Zumkeller

walter.zumkeller@

medizin.uni-halle.de

Accepted for publication 8 March 2001
Glioma tissues showed an enhanced expression of IGF-I and IGF-II mRNA transcripts compared with normal brain. ${ }^{3}$ In situ hybridisation and immunocytochemistry showed a strong expression of both IGF-I and IGF-II mRNA molecules and of their protein products in the tumour cells of astrocytomas and meningiomas. ${ }^{4}$ However, concentrations of IGFs were not raised in cerebrospinal fluid (CSF) from patients with tumours. ${ }^{5}$ In anaplastic oligodendroglioma, two IGF-I cDNAs resulting from alternative splicing of the IGF-I primary transcript were identified, which encode two different precursor proteins, corresponding to Ea IGF-I and Eb IGF-I. ${ }^{6}$ IGF-I greatly enhances the three dimensional growth of human glioblastomas. ${ }^{7}$ Transfection of rat C6 glioma cells with an episome based vector encoding antisense IGF-I cDNA results in a loss of tumorigenicity and also regression of established brain glioblastomas when injected into the tumour.

Both meningiomas and gliomas express IGF-II mRNA. ${ }^{9}$ In meningiomas, high IGF-II mRNA expression was detected..$^{10} \mathrm{~A}$ significant correlation was found between a high IGF-II/ IGFBP-2 ratio and anaplastic/atypical histopathology in sporadic meningiomas, indicating that higher free IGF-II values may provide a greater stimulus for proliferation. ${ }^{11}$ IGF-II mRNA was found in higher amounts in benign meningiomas than in malignant glioblastomas and astrocytomas, whereas the content of immunoreactive IGF-II peptide was comparable. ${ }^{12}$ IGF-II mRNA expression appears to parallel the growth rate in the LI human glioblastoma cell line. ${ }^{13}$

Upregulation of IGF-II expression is a feature of TrkA but not TrkB activation in SH-SY5Y neuroblastoma cells, suggesting that IGF-II is a component of the effector mechanism of TrkA activation. ${ }^{14}$ It appears that IGF-II may counteract the programmed cell death effects of retinoic acid, ${ }^{15}$ and the antiproliferative agent interferon $\gamma$ inhibits DNA synthesis and IGF-II expression in neuroblastomas. ${ }^{16}$ In addition, the cytostatic agent suramin blocks IGF-II dependent cell growth by preventing IGF-I receptor activation. ${ }^{17}$

In choroid plexus papillomas, immunoreactive IGF-II was detectable, whereas normal choroid plexus was negative for IGF-II. In addition, IGFBP-2 was positive in the endothelium and vascular media in the normal choroid plexus, whereas it was negative or weakly positive in choroid plexus papillomas. ${ }^{18}$ It was concluded that IGF-II could be a useful marker for choroid plexus papilloma in differential diagnosis. $^{19}$

Genomic imprinting is characterised by a differential expression of the two parental alleles of an autosomal gene. Loss of imprinting (LOI) or biallelic expression may, as an epigenetic factor, play an important role in tumorigenesis. ${ }^{20}$ LOI 
of IGF-II occurs in medulloblastomas and gliomas. $^{21} 22$ The normally imprinted IGF-II gene lacks imprint in the leptomeninges and choroid plexus of the brain. However, monoallelic expression for IGF-II was found in $73 \%$ of the meningiomas, which is in contrast to the lack of imprinting status of IGF-II in leptomeninges. ${ }^{23}$ Abnormal imprinting of IGF-II may contribute towards tumorigenesis and the modulation of aberrant imprinting status may result in new therapeutic approaches.

\section{IGF receptors}

The type I IGF receptor is composed of subunits and shows tyrosine kinase activity, whereas the type II IGF receptor is a monomer of $250 \mathrm{kDa}$. Receptors for IGFs are found throughout the normal brain as well as in astrocytomas and glioblastomas. ${ }^{24} 25$ Two types of IGF receptor were identified in human gliomas. ${ }^{25}{ }^{26}$ IGF-I binding was significantly higher in gliomas and meningiomas compared with normal adult brain. ${ }^{27}$ In addition, both enhanced binding of IGF-II to glioblastoma membranes and increased IGF-II receptor concentrations were found in glioblastomas. ${ }^{28}$ The IGF-I receptor is expressed by primitive neuroectodermal tumour cell lines in vitro and an activated receptor is important for cell proliferation in vitro. ${ }^{29}$ IGF-I stimulates human primitive neuroectodermal tumour cells by phosphorylation of the IGF-I receptor involving the mitogen activated protein (MAP) kinase pathway. ${ }^{30}$ In MCF-7 cells, which stably express the receptor mutated at the C-terminus, decreased clonogenicity in soft agar and increased sensitivity to UV irradiation were seen. ${ }^{31}$

Mutant IGF-I receptors transfected into C6 rat glioblastoma cells can act as dominant negatives inducing apoptosis. ${ }^{32} \mathrm{C} 6$ cells expressing an antisense IGF-I receptor RNA elicit an antitumour response, leading to complete brain tumour regression. ${ }^{33}{ }^{34}$

\section{IGFBPs}

Many tumours express IGFBPs, which regulate the bioavailability and bioactivity of IGFs. Patients with malignant CNS tumours showed increased IGFBP-2 concentrations in CSFpatients with CNS tumours and microscopically detectable malignant cells in their CSF had the highest IGFBP-2 values. ${ }^{35}$ Thus, IGFBP-2 in CSF might be a useful specific marker for malignant CNS tumours. In addition, raised IGFBP-3 concentrations were found in the CSF of $70 \%$ of patients with CNS tumours and in $86 \%$ of patients with tumours and microscopically detectable malignant cells in their CSF. The IGFBP-3 protease activity in CSF was increased in $94 \%$ of those patients with CNS tumours of high grade histological malignancy. ${ }^{36}$

Meningiomas and, to a lesser degree, malignant gliomas were found to synthesise IGFBP-1, supporting the notion that IGFBPs contribute towards the growth of CNS tumours in humans. ${ }^{37}$ Astrocytomas secrete various IGFBPs, including IGFBP- $1 .{ }^{38}$ Glioblastoma cell lines were found to express mRNA for IGFBP-1 (42\% of cell lines), IGFBP-2 (65\%), IGFBP-3 (97\%), IGFBP-4 (3\%), IGFBP-5 (74\%), IGFBP-6 (94\%), and IGFBP-7 (87\%) as determined by the polymerase chain reaction. In addition, membrane bound IGFBPs $(44,50$, and $60 \mathrm{kDa})$ were found. $^{39}{ }^{40} \mathrm{C} 6$ glioma cells stably transfected with connexin 43 cDNA show a lower rate of proliferation, which was associated with high IGFBP-4 mRNA expression, ${ }^{41}$ indicating that the negative modulator IGFBP-4 might be responsible for the reduced proliferative capacity of these transfected cells.

\section{Conclusion}

The IGF system is involved in tumour growth regulation both in vitro and in vivo. These factors may act as progression and survival factors upregulating tumour growth and blocking apoptosis, respectively. ${ }^{42}$ The IGF system may therefore be a target of therapeutic intervention in CNS malignancy. Gene therapy of glioblastoma in rats by an episome based transcriptional cassette expressing antisense IGF-I cDNA has proved effective. ${ }^{43} \mathrm{~A}$ gene transfer protocol using IGF-I receptor antisense cDNA has progressed into human clinical trials for the treatment of brain tumours. ${ }^{44}$ Clinical trials that will provide crucial information for the improvement of gene transfer technology for humans are under way and should improve the outcome for patients suffering from CNS tumours.

1 Zumkeller W. The effects of insulin-like growth factors on brain myelination and their potential therapeutic application in myelination disorders. Eur 7 Paediatr Neurol 1997;1:91-101.

2 Glick RP, Lichtor T, Unterman TG. Insulin-like growth factors in central nervous system tumors. F Neurooncol 1997;35:315-25.

3 Sandberg AC, Engberg C, Lake M, et al. The expression of insulin-like growth factor I and insulin-like growth factor II genes in the human fetal and adult brain and in glioma. Neurosci Lett 1988;93:114-19.

4 Antoniades HN, Galanopoulos T, Neville-Golden J, et al. Expression of insulin-like growth factors I and II and their receptor mRNAs in primary human astrocytomas and meningiomas; in vivo studies using in situ hybridization and immunocytochemistry. Int f Cancer 1992;50:215-22.

5 Glick RP, Unterman TG. Radioimmunoassay of insulin-like growth factors I and II in the cerebrospinal fluid of patients with pituitary and other central nervous system tumors. Neurosurgery 1995;36:556-63.

6 Sandberg-Nordquist AC, Stahlbom PA, Reinecke M, et al. Characterization of insulin-like growth factor 1 in human primary brain tumors. Cancer Res 1993;53:2475-8.

7 Morford LA, Boghaert ER, Brooks WH, et al. Insulin-like growth factors (IGF) enhance three-dimensional (3D) growth of human glioblastomas. Cancer Lett 1997;115:8190.

8 Trojan J, Johnson TR, Rudin SD, et al. Treatment and prevention of rat glioblastoma by immunogenic C6 cells expressing antisense insulin-like growth factor I RNA. Science 1993;259:94-7.

9 Glick RP, Unterman TG, Lacson R. Identification of insulin-like growth factor (IGF) and glucose transporter-1

10 Lichtor L, Kurpakus MA, Gurney ME. Differential expression of insulin-like growth factor II in human meningiomas. Neurosurgery 1991;29:405-10.

11 Nordqvist AC, Peyrard M, Pettersson H, et al. A high ratio of insulin-like growth factorII/insulin-like growth factor binding protein 2 messenger RNA as a marker for anaplasia in meningiomas. Cancer Res 1997;57:2611-14.

12 Hultberg BM, Haselbacher G, Nielsen FC, et al. Gene expression of insulin-like growth factor II in human intracranial meningioma. Cancer 1993;72:3282-6.

13 Melino G, Stephanou A, Annicchiarico-Petruzzelli M, et al. IGF-II mRNA expression in LI human glioblastoma cell line parallels cell growth. Neurosci Lett 1992;144:25-8.

$14 \mathrm{Kim}$ CJ, Matsuo T, Lee KH, et al. Up-regulation of insulinlike growth factor-II expression is a feature of TrkA but not Pathol 1999;155:1661-70. 
15 Melino G, Stephanou A, Annicchiarico-Petruzzelli M, et al. Modulation of IGF-2 expression during growth and differentiation of human neuroblastoma cells: retino
induce IGF-2. Neurosi Lett 1993;151:187-91.

16 Martin DM, Carlson RO, Feldman EL. Interferon-gamma inhibits DNA synthesis and insulin-like growth factor-II expression in human neuroblastoma cells. F Neurosci Res 1993;34:489-501.

17 Sullivan KA, Kim B, Buzdon M, et al. Suramin disrupts insulin-like growth factor-II (IGF-II) mediated autocrine growth in human SH-SY5Y neuroblastoma cells. Brain Res 1997;744:199-206.

18 Kubo S, Ogino S, Fukushima $\mathrm{T}$, et al. Immunohistochemical study of insulin-like growth factor II (IGF-II) and insulin-like growth factor binding protein-2 (IGFBP-2) choroid plexus papilloma. Neurol Res 1999;21:339-44.

19 Kubo S, Ogino S, Fukushima T, et al. Immunocytochemical detection of insulin-like growth factor II (IGF-II) in choroid plexus papilloma: a possible marker for differential diagnosis. Clin Neuropathol 1999;18:74-9.

20 Joyce JA, Schofield PN. Genomic imprinting and cancer. $\mathcal{F}$ Clin Pathol: Mol Pathol 1998;51:185-90.

21 Albrecht S, Waha A, Koch A, et al. Variable imprinting of H19 and IGF2 in fetal cerebellum and medulloblastoma. $\mathcal{F}$ Neuropathol Exp Neurol 1996;55:1270-6.

22 Uyeno S, Aoki Y, Nata M, et al. IGF2 but not H19 shows loss of imprinting in human glioma. Cancer Res 1996;56 5356-9.

23 Müller S, Zirkel D, Westphal M, et al. Genomic imprinting of IGF2 and H19 in human meningiomas. Eur f Cancer 2000;36:651-5.

24 Merrill MJ, Edwards NA. Insulin-like growth factor-I receptors in human glial tumors. F Clin Endocrinol Metab 1990;71:199-209.

25 Zumkeller W, Biernoth R, Kocialkowski S, et al. Expression and synthesis of insulin-like growth factor (IGF)-I, -II and their receptors in human glioma cell lines. Int $\mathcal{F}$ Oncol 1996;9:983-92

26 Gammeltoft S, Ballotti R, Kowalski A, et al. Expression of two types of receptor for insulin-like growth factors in two types of receptor for insulin-like growth factors

27 Glick RP, Gettleman R, Patel K, et al. Insulin and insulin-like growth factor I in brain tumors: binding and in vitro effects. Neurosurgery 1989;24:791-7.

28 Sara VR, Prisell P, Sjögren B, et al. Enhancement of insulinlike growth factor 2 receptors in glioblastoma. Cancer Let 1986;32:229-34.

29 Chin LS, Yung WK, Raffel C. Two primitive neuroectodermal tumor cell lines require an activated insulin-like growth factor I receptor for growth in vitro. Neurosurgery 1996;39: 1183-90.

30 Patti R, Reddy CD, Geoerger B, et al. Autocrine secreted insulin-like growth factor-I stimulates MAP kinasedependent mitogenic effects in human primitive neuroectodermal tumor/medulloblastoma. Int $\mathcal{f}$ Oncol 2000;16: 577-84.
31 Liu Y, Lehar S, Corvi C, et al. Expression of the insulin-like growth factor I receptor $\mathrm{C}$ terminus as a myristylated protein leads to induction of apoptosis in tumor cells. Cancer Res 1998;58:570-6.

32 Burgaud JL, Resnicoff M, Baserga R. Mutant IGF-I receptors as dominant negatives for growth and transformation. Biochem Biophys Res Commun 1995;214:475-81.

33 Resnicoff M, Tjuvajev J, Rotman HL, et al. Regression of C6 rat brain tumors by cells expressing an antisense insulinlike growth factor I receptor RNA. F Exp Ther Oncol 1996; 1:385-9.

34 Resnicoff M, Baserga R. The role of the insulin-like growth factor I receptor in transformation and apoptosis. Ann NY Acad Sci 1998;842:76-81.

35 Müller HL, Oh Y, Lehrnbecher T, et al. Insulin-like growth factor-binding protein-2 concentrations in cerebrospinal fluid and serum of children with malignant solid tumors or acute leukemia. F Clin Endocrinol Metab 1994;79:428-34.

36 Müller HL, Oh Y, Gargosky SE, et al. Concentrations of insulin-like growth factor (IGF)-binding protein-3 (IGFBP-3), IGF, and IGFBP-3 protease activity in cerebrospinal fluid of children with leukemia, central nervous system tumor, or meningitis. F Clin Endocrinol Metab 1993;77:1113-19.

37 Unterman TG, Glick RP, Waites GT, et al. Production of insulin-like growth factor-binding proteins by human central nervous system tumors. Cancer Res 1991;51:3030-6.

38 Zumkeller W, Sääf M, Rähn T. Insulin-like growth factor (IGF)-I, -II and IGF-binding proteins in the cyst fluid of a patient with astrocytoma. Childs Nerv Syst 1993;9:100-3.

39 Zumkeller W, Müller D, Müller S, et al. Expression and synthesis of insulin-like growth factor-binding proteins in human glioma cell lines. Int f Oncol 1998;12:129-35.

40 Zumkeller W, Müller D, Biernoth R, et al. The IGF/IGFBP system in CNS malignancy [abstract]. F Clin Pathol: $M o l$ Pathol 2001;54:54.

41 Bradshaw SL, Naus CC, Zhu D, et al. Alterations in the synthesis of insulin-like growth factor binding proteins and insulin-like growth factors in rat C6 glioma cells transfected with a gap junction connexin43 cDNA. Regul Pept 1993;48:99-112.

42 Zumkeller W, Schwab M. Insulin-like growth factor system in neuroblastoma tumorigenesis and apoptosis: potential diagnostic and therapeutic perspectives. Horm Metab Res 1999;31:138-41.

43 Johnson TR, Trojan J, Anthony DD, et al. Gene therapy of rat brain glioblastoma by an episome-based transcriptional cassette expressing antisense IGF-I cDNA. Indian $\mathcal{f}$ Biochem Biophys 1994;31:1-13.

44 Culver KW. Gene therapy for malignant neoplasms of the CNS. Bone Marrow Transplant 1996;18(suppl 3):S6-9. 